\title{
Trisomy 19
}

National Cancer Institute

\section{Source}

National Cancer Institute. Trisomy 19. NCI Thesaurus. Code C84284.

A chromosomal abnormality consisting of the presence of a third copy of chromosome 19 in somatic cells. 